\title{
Obstetric outcome of twin pregnancies at tertiary care teaching hospital
}

\author{
Santosh Meena ${ }^{1}$, Kamlesh Yadav', Rajdeep Meena ${ }^{2}$
}

\begin{abstract}
${ }^{1}$ Department of Obstetric and Gynaecology, Sardar Patel Medical College, P.B.M and Associated Group of Hospital, Bikaner, Rajasthan, India

${ }^{2}$ Department of Obstetric and Gynaecology, Government Medical College Kota, Rajasthan, India
\end{abstract}

Received: 17 June 2016

Accepted: 08 July 2016

\author{
*Correspondence: \\ Dr. Santosh Meena, \\ E-mail: drmithlesh.meena2608@gmail.com
}

Copyright: ( ) the author(s), publisher and licensee Medip Academy. This is an open-access article distributed under the terms of the Creative Commons Attribution Non-Commercial License, which permits unrestricted non-commercial use, distribution, and reproduction in any medium, provided the original work is properly cited.

\begin{abstract}
Background: Twin Pregnancy is considered as a high risk pregnancy. According to Hellin's rule one in about 89 natural pregnancies ends in birth of twins, one in 892 birth is triplet and one in 893 birth is Quadruplets. Maternal obstetric complications includes preterm labour, anaemia, pregnancy induced hypertension, eclampsia, complication of labour and postpartum haemorrage. Foetal complications include prematurity, low birth weight, perinatal mortality. The perinatal mortality rate associated with twin pregnancy is 4 time greater than with singleton pregnancy.

Methods: It was one year observational study from 2011 to 2012. All women admitted to the labour ward with twin pregnancy after 28 weeks gestation were included in this study. Data obtained at the time of delivery included maternal age, parity, gestational age at the time of delivery \& foetal weight.

Results: A total of 18666 deliveries conducted, there were 206 cases of twin deliveries constituting incidence of $1.1 \%$ (1:90). Majority of cases were 20-25 year age group (58\%). Mean age of cases was 24.94 year. Majority of cases were primigravidas (45\%). Majority of women were unbooked (62\%). Only $28 \%$ were registered, $43 \%$ were presented with preterm labour, PIH noted in $18 \%$, anemia in $15 \%$ and APH in 3\%. Most common cause of neonatal morbidity was preterm birth (41.5\%). Perinatal mortality was maximum $100 \%$ in babies with birth weight $<1000 \mathrm{gm} \& 76.92 \%$ in 1000-1499gm weight. Most common cause of neonatal death was very low birth weight.

Conclusions: Twin pregnancies are associated with increasing with morbidity of mother and foetus. Most of babies head respiratory distress or had developed neonatal sepsis. These death can be prevented by averting preterm birth by combined measures like good rest, cervical encirclage, administration of steroid in preterm labour, by institutional delivery and provision of level 3 neonatal care.
\end{abstract}

Keywords: Twin pregnancy, Maternal outcome, Perinatal outcome

\section{INTRODUCTION}

Accordingly to Hellin's rule, mathematical frequency of multiple birth in twin is 1 in 80 pregnancies, Triplets 1 in $80^{2}$,quadruplets 1 in 80 so on. ${ }^{1-3}$ Twin births is by far the most common multiple births. The cause of twining is not known. The frequency of monozygotic twins remains constant throughout the globe and probably related to maternal environment. It is the wide variation in the prevalence of binovular twins which is responsible for fluctuation in the overall incidence of twins in different population. The prevalence of dizygotic twins is related to, race, hereditary, advancing age of mother, parity, personal history, ovulation inducing drugs eg, gonadotropin 20_40\% and clomiphene citrate 5_6\% oral contraceptive. $^{3-5}$ Compared to singleton pregnancies perinatal mortality, morbidity and longterm neuro developmental disability are increased 5-10 fold in twin pregnancies.

\section{METHODS}

This prospective study was conducted in 100 patients with twin pregnancy in Department of Obstetrics \& Gynaecology, Sardar Patel Medical College, P.B.M. and Associated Group of Hospitals Bikaner 2011 to 2012.The 
total number of cases included were 100 . Women with twin pregnancy completing 28 weeks of gestations with or without medical and obstetric complications were included in the study. However, twin pregnancy discharged after taking conservative management was excluded. Individual patient parameters like age, parity, duration of gestation physical examination mode of delivery, antepartum, intrapartum, and postpartum complications were tabulated. Neonatal morbidity and mortality in the first week were also noted results of routine and specialized investigations and ultrasonography were recorded. Data thus obtained was analyzed and results studied.

\section{RESULTS}

Table 1: Distribution of cases according to age $(\mathbf{n}=\mathbf{1 0 0})$.

\begin{tabular}{|lll|}
\hline Age ( Years) & No & $\%$ \\
\hline$<20$ & 3 & 3.0 \\
\hline $20-25$ & 58 & 58.0 \\
\hline $26-30$ & 31 & 31.0 \\
\hline $31-35$ & 7 & 7.0 \\
\hline$>35$ & 1 & 1.0 \\
\hline Total & 100 & 100.00 \\
\hline
\end{tabular}

This study was done from July 2011 to December 2012 in "Department of Obstetrics and Gynaecology P.B.M and Associated group of Hospitals, attached to Sardar Patel Medical College, a tertiary care hospital in Bikaner". During this duration out of total 18666 deliveries, there were 206 cases of twin pregnancies giving an incidence of $1.102 \%$ (1:90) In this study, majority of the cases were of relatively younger age. $58 \%$ of the women in our study belonged to the age group of 20-25 years. The mean maternal age was $24.94 \pm 3.77$ years (Table 1 ).

In our study out of 100,62 cases who were admitted in labour as emergency cases, while $28 \%$ of cases were registered. In our study 62 cases were emergency in which $24(38.2 \%)$ were perinatal deaths while among registered cases perinatal death rate was only $18.82 \%$. In our study incidence of anaemia was $80 \%$ and maximum cases $(70 \%)$ had $\mathrm{Hb} 7-9 \mathrm{gm} \%, 20 \%$ cases had $\mathrm{Hb}$ $>9 \mathrm{gm} \%$ and and only $10 \%$ had $\mathrm{Hb}<7 \mathrm{gm} \%$. In this study, $69.56 \%$ of LSCS were done for malpresentations followed by $13.04 \%$ cases for PIH with failed induction, $4.35 \%$ each for placenta previa and abruptio placentae, $4.35 \%$ for NPOL and $4.35 \%$ for fetal distress (Table 2).

In our study antenatal complications were encountered in $82 \%$ of cases, the most common being preterm labour in $43 \%$ followed by $\mathrm{PIH}$ in $18 \%$, anemia in $15 \%$, abruptio placenta in $2 \%$, placenta previa in $1 \%$, polyhydramnios in $2 \%$, and antepartum eclampsia in $1 \%$ cases. Only $18 \%$ of cases had no complications during their antenatal period, (Table 3). In our study, intrapartum complications occurred in $41 \%$ of cases with the most common complication being malpresentation in $34 \%$ cases. Nonprogress of labour occurred in $3 \%$, hand prolapse in $2 \%$ and cord presentation in $2 \%$ cases.

Table 2: Various Indications for LSCS.

\begin{tabular}{|lll|}
\hline Indication & No. & $\%$ \\
\hline Malpresentation & 16 & 69.56 \\
\hline $\begin{array}{l}\text { PIH with failed } \\
\text { induction }\end{array}$ & 3 & 13.04 \\
\hline NPOL & 1 & 4.35 \\
\hline Fetal distress & 1 & 4.35 \\
\hline Placenta previa & 1 & 4.35 \\
\hline Abruptio placentae & 1 & 4.35 \\
\hline Total & 23 & 100.00 \\
\hline
\end{tabular}

Table 3: Distribution of cases according to antepartum complications.

\begin{tabular}{|lll|}
\hline Antepartum complications & No. & $\%$ \\
\hline Preterm Labour & 43 & 43.0 \\
\hline Pregnancy induced hypertension & 18 & 18.0 \\
\hline Anemia & 15 & 15.0 \\
\hline Placental abruption & 2 & 2.0 \\
Placenta Previa & 1 & 1.0 \\
\hline Polyhydramnios & 2 & 2.00 \\
\hline Anterpartum eclampsia & 1 & 1.00 \\
\hline None & 18 & 18.00 \\
\hline
\end{tabular}

Table 4: Distribution of cases according to neonatal morbidity and mortality twins $(n=200)$.

\begin{tabular}{|lll|}
\hline & No. & $\%$ \\
\hline Preterm birth & 83 & 41.5 \\
\hline Discordant growth & 40 & 20 \\
\hline Neonatal death & 22 & 11 \\
\hline $\begin{array}{l}\text { Intrauterine death or } \\
\text { one of or more fetus }\end{array}$ & 15 & 7.50 \\
\hline Birth asphyxia & 13 & 6.50 \\
\hline Hypothermia & 13 & 6.50 \\
\hline Infections & 6 & 3.0 \\
\hline $\begin{array}{l}\text { Neonatal } \\
\text { hyperbilirubinemia }\end{array}$ & 4 & 2.0 \\
\hline $\begin{array}{l}\text { Twin-twin transfusion } \\
\text { syndrome }\end{array}$ & 2 & 1.0 \\
\hline Fetal anomalies & 2 & 1.0 \\
\hline
\end{tabular}

In our study, the most common postpartum complication was atonic PPH in 5\% cases. All cases of atonic $\mathrm{PPH}$ were managed by IV oxytocin, methergin IM prostaglandins and replacement of blood loss by urgent blood transfusion. Postpartum eclampsia was present in $2 \%$ cases; there was one maternal death in this series. The risk of post-partum hemorrhage is minimized in our institution by routine administration of 5-10 U oxytocin, fundal massage and controlled cord traction method in delivery of placenta. It is a sound practice to continue the 
oxytocin drip for at least one hour, following the delivery of second baby.

In our study most common cause of neonatal morbidity was preterm birth in $41.50 \%$ babies followed by discordant growth in $20.0 \%$, birth asphyxia in $6.50 \%$ and hypothermia in $6.50 \%$. Intrauterine death of one or both fetus was seen in $7.50 \%$, twin-twin transfusion syndrome occurred in $1.0 \%$, neonatal hyperbilirubinemia in $2.0 \%$ and infections in $3.0 \%$ babies. Fetal anomaly as anencephaly and meningomyelocele was seen in $2(1.0 \%)$ new-borns. Neonatal death occurred in $22(11.0 \%)$ twin new-born (Table 4). In our study most of the new-born's had birth weight 2000-2499 gms (33\% of 1st baby and $39 \%$ of 2 nd baby). $23 \%$ of 1 st babies and $20 \%$ of 2 nd babies were $>2500 \mathrm{gms}$ birth weight. Birth weight was $1500-1999$ gms in $28 \%$ of 1 st babies, and $24 \%$ of 2 nd babies. $16 \%$ of 1 st and $17 \%$ of 2 nd babies were below 1500 gms. Only $3 \%$ of 1 st babies and $4 \%$ of 2 nd babies were below 1000 gms. Mean birth weight was $1.93+0.44$ $\mathrm{kg}$ (Table 5).

Table 5: Distribution of cases according to weight of the New born $\mathrm{N}=(200)$.

\begin{tabular}{|lll|}
\hline Weight (gms) & $\mathbf{1}^{\text {st }}$ Baby & $2^{\text {nd }}$ Baby \\
\hline$<1000$ & 3 & 4 \\
\hline $1000-1499$ & 13 & 13 \\
\hline $1500-1999$ & 28 & 24 \\
\hline $2000-2499$ & 33 & 39 \\
\hline$>2500$ & 23 & 20 \\
\hline Total & 100 & 100 \\
\hline
\end{tabular}

\section{DISCUSSION}

Twin pregnancy constitutes a important portion of high risk pregnancies attending any obstetric health care facility. In our study $58 \%$ of the women belongs to 20-25 years of age group. Most of the cases were primigravida. This was comparable to study done by Yuel Veronica Irene et al Mean age of the cases was $24.94 \pm 3.77$ year. $^{6}$ In this study incidence of anaemia was $80 \%$.Maximum cases $(70 \%)$ had haemoglobin 7_9 gm,20\%cases had hb $>9$ gmhad $\mathrm{hb}<7 \mathrm{gm} \% \mathrm{hb}$ seen in only $10 \%$ cases. This was comparable by study done by naushba et al done, in which incidence of anaemia was $65 \%$. $^{7}$ Most common Indication of LSCS was malpresentation in (69.56\%) which was comparable by study done by yuel veronica Irene and kaur vaneetin in 2007 who found malpresention is commonest indication of caesrean section in $71 \%$ of cases. Antepartum complications occurred in $82 \%$ of the casees, the most common being preterm labour (43\%) followed by PIH (18\%), anemia (15\%) and APH (3\%). Intrapartum complications occurred in $41 \%$ cases. Most common complication was malpresentation in $34 \%$ followed by NPOL in 3\%. Postpartum complication occurred in $10 \%$ of cases, most common complication being atonic PPH in 5\% and postpartum eclampsia in $2 \%$. This was comparable to study done by Irene YV and
Kaur V who found preterm labour in $57.5 \%$ cases, PIH in $18 \%$ cases, anemia in $28 \%$, abruptio plaentae in $1 \%$, placenta previa in $1 \%$, gestational diabetes in $0.5 \%$ and chronic hypertension in $0.5 \%$. In study done by R Rani, S Kharoon et al most common antenatal complication was anemia in $60-96 \%$ cases. $^{8}$ The reason for such a high incidence of anemia in their study was because most of their cases $\left(2 / 3^{\text {rd }}\right)$ were unbooked and thus did not receive any antenatal care. In their study, $45.45 \%$ cases had preterm labour, PIH was present in $42.25 \%$, hydramnios in $34.23 \%$, abruption in $10.16 \%$ and placenta previa in $5.34 \%$ cases). In study done by Rani R, Kharoon $\mathrm{S}$ et al. PROM was seen in $13.9 \%$ cases, in coordinate uterine action in $5.35 \%$, hypotonic uterine inertia in $7.48 \%$ and cord prolapse in $2.14 \%$.Interlocking of twins in a rare malpresentation occurring one time per every 1000 twins and per every 50,000 births. The perinatal mortality of this complication is high, $62-84 \%$, probably because most cases are not recognized until late in the expulsive phase of labour. Among twins, most common cause of neonatal morbidity was preterm birth in $41.5 \%$ followed by discordant growth in $20 \%$ and birth asphyxia in $6.50 \%$. Perinatal mortality was maximum $(100 \%)$ in babies with birth weight $<1000$ gms and $76.92 \%$ in babies birth weight 1000-1499 gms. In our study most of the newborn had birth weight between 2000-2499 gms (33\% of $1^{\text {st }}$ baby and $39 \%$ of $2^{\text {nd }}$ babies $) .>2500$ gms birth weight was found in $23 \%$ of $1^{\text {st }}$ babies and $20 \%$ of $2^{\text {nd }}$ babies, birth weight was 1500-1999 gms in 28\% of 1st babies and $24 \%$ of 2 nd babies. Birth weights $1000-1499$ gms in $13 \%$ of $1^{\text {st }}$ babies and $13 \%$ of 2 nd babies. Birth weight was found $<1000 \mathrm{gms}$ in $3 \%$ of $1^{\text {st }}$ babies and $4 \%$ of $2^{\text {nd }}$ babies (Table 5). Most of the newborns had birth weight of 2000-2499 gm with the mean birth weight being $1.93+0.44 \mathrm{~kg}$. This was compared with study done by Pandole A, Swamy MSC et at. ${ }^{9}$ who found the most common birth weight was between 1550-2000 gms seen in $35.63 \%$ of 1 st babies and $39.39 \%$ of 2 nd babies. Birth weight of $2050-2500 \mathrm{gms}$ was found in $25.53 \%$ of $1^{\text {st }}$ babies and $28.72 \%$ of $2^{\text {nd }}$ babies while birth weight > 2500 gms was found in only $12.76 \%$ of 1 st babies and $5.15 \%$ of 2 nd babies. Birth weight $1050-1500$ gms was found in $20.2 \%$ of 1 st babies and $20.74 \%$ of 2 nd babies. Birth weight $<1000$ gms was seen in $5.85 \%$ of 1 st babies and $5.31 \%$ of 2 nd babies. Prematurity is leading cause of perinatal mortality as was also revealed by Ziadeh SZ. ${ }^{10}$

\section{CONCLUSION}

Twin pregnancy remains a continuing perinatal challenge. Complications associated with twin pregnancies definitely more than singletone pregnancies. All twin pregnancies should have a mandatory hospital delivery. Early diagnosis, adequate antenatal, intranatal, postpartum care is necessary to improve the outcome. Complications associated with twin pregnancies cannot prevented but can be detected early and controlled adequately by proper and promt management. 
Funding: No funding sources

Conflict of interest: None declared

Ethical approval: The study was approved by the Institutional Ethics Committee

\section{REFERENCES}

1. Chamberlain GPV. Multiple pregnancy. In: Baker PN. Obstetric. $15^{\text {th }}$ edition. UK: Arnold; 1990:13641.

2. National Centre for Health Statistics. Multiple Birth.

3. Naheed I, Zaineb A, Almas S. Twin pregnancy, (high risk for mother and fetus). Pak Postgrad Med J. 2001;12:50-4.

4. La Sala GB, Gallinelli A, Nicoli A, Villani MT, Nucera G. Pregnancy loss and assisted reproduction: preliminary results after the law 40/2004 in Italy.

5. Child TJ, Henderson AM, Jan Tan SL. The desire for multiple pregnancy in male and female infertility patient. Hum Repord. 2004;19:558-61.
6. Irene YV, Kaur V. An analytical study of pregnancy outcome in multifetal gestation. J Obstet Gynecol index. 2007;57(6):509-12.

7. Rijwan N, Abbasi RM, Mughal R. Maternal morbidity and foetal outcome in twin pregnancies. J Ayuv Med Coll. Abbottabad. 2010;22(2).

8. Rani S, Kharoon R, Arora S, Raghavan. Perinatal mortalitiy in twin pregnancy: a retrospective study. J Obstet Gynecol Ind. 1995;45:723-31.

9. Pandole A, Sardespande SN. Perinatal Mortality in twin pregnancy- a retrospective analysis. J Obstet Gynecol. 2003;53(2):138-9.

10. Ziadeh S. Outcome of twin pregnancies in north Jordan. J Obs Gyn. 2000;20:492-94.

Cite this article as: Meena S, Yadav K, Meena R. Obstetric outcome of twin pregnancies at tertiary care teaching hospital. Int J Reprod Contracept Obstet Gynecol 2016;5:2752-5. 